\title{
Evaluasi Karakter Morfo-fisiologis Sumber Daya Genetik Padi Berumur Genjah
}

\author{
DOI 10.18196/pt.2014.025.66-73
}

\author{
Mamik Setyowati*, Nurul Hidayatun, Sutoro, Hakim Kurniawan \\ Balai Besar Penelitian dan Pengembangan Bioteknologi dan Sumberdaya Genetik Pertanian, \\ Jl. Ragunan 29, Pasar Minggu, Jakarta Selatan 12540, Indonesia, \\ ${ }^{*}$ Corresponding author: setyomamik@gmail.com
}

\begin{abstract}
ABSTRAK
Varietas padi berumur genjah dan produktivitas tinggi dapat dihasilkan apabila tersedia sumber daya genetik (SDG) pada tingkat keragaman yang memadai. Karakter morfologis dan fisiologis seperti ketebalan daun dan laju pertumbuhan tanaman dapat berpengaruh langsung terhadap potensi produktivitas tanaman. Evaluasi terhadap karakteristik laju perkecambahan benih, laju pertumbuhan tanaman, dan efisiensi penyerapan unsur hara nitrogen telah dilakukan pada sebanyak 25 aksesi padi. Laju perkecambahan benih galur B1 1283-6C-PN-5-MR-34-1-1-3, Lariang, B1 1742-RS-2-3-MR-34-1-2-3 mencapai 1,0-1,3 g/lubang/hari selama periode perkecambahan benih, sedangkan varietas Dodokan dan Silugonggo menunjukkan laju perkecambahan benih sebesar 0,7-0,8 g/lubang/hari. Galur-galur Danau Atas, B. 1 1283-6C-PN-5-MR-2-3-SI-1 -2-1 - 1, B1 1742-RS-2-3-MR-34-1-2-3 dan B1 1742 -RS-23-MR-34-1-4-1 memperlihatkan penampilan yang sangat baik. Bahkan galur-galur B1 1742-RS-2-3-MR-34-1-1-3, B1 1742-RS-2-3-MR-34-1-1-4 dan B1 1742-RS-2-3-MR-34-1 -4-1 menghasilkan produksi gabah lebih tinggi dibandingkan dengan varietas Silugonggo dan Dodokan. Galur-galur tersebut memiliki umur panen 96 hari setelah tanam.

Kata kunci: Padi, Laju perkecambahan benih, Umur genjah, Pertumbuhan tanaman
\end{abstract}

\begin{abstract}
Rice varieties with short maturity and high productivity can be achieved when there is available genetic resources in a sufficient level of variability. Morphological characters, such as leaf thickness and crop growth rate, could affect in crop productivity. Evaluation of seed germination rate, crop growth rate, and their efficiency used for nitrogen have been done on 25 accessions of rice. Seed germination rate of B1 1283-6C-PN-5-MR-34-1-1-3, Lariang, B11742-RS-2-3-MR-34-1-2-3 reached 1,0-1,3 g/hill/day during seed initiation, while Dodokan and Silugonggo reached 0.7-0.8 g/hill/day. Danau Atas, B.11283-6C-PN-5-MR-2-3-SI-1-2-1-1, B11742-RS-2-3-MR-34-1-2-3 and B11742-RS-2-3-MR-34-1-4-1 lines show good perfomance, moreover B11742-RS-2-3-MR-34-1-1-3, B11742-RS-2-3-MR-34-1-1-4 and B11742-RS-2-3-MR-34-1-1-4 lines produced grain yield higher than Silugonggo and Dodokan varieties. Those lines could be harvested at about 96 days after planting.

Keywords: rice, seed initiation rate, short maturity, crop growth
\end{abstract}

\section{PENDAHULUAN}

Tanaman padi umumnya berumur 90 hingga 180 hari sejak semai hingga panen, tergantung kultivar / varietas dan kondisi lingkungan budidaya. Namun demikian, durasi pertumbuhan optimal untuk memberikan hasil maksimal pada kebanyakan varietas padi Indica di daerah tropis adalah 120 hari (Tanaka et al., 1976). Total biomasa meningkat secara linear selama periode pertumbuhan vegetatif pada umur 95 hingga 135 hari, dan hasil biji maksimum (sekitar 8-9 ton/ ha) dapat dicapai oleh beberapa varietas pada umur 110-130 hari (Akita, 1989).
Penggunaan varietas padi berumur genjah akan menguntungkan dalam banyak hal, diantaranya adalah: mengurangi resiko gangguan lingkungan (hama, penyakit, kekeringan), menghemat biaya pengelolaan selama budidaya, dan dapat meningkatkan fleksibilitas dalam pengelolaan strategi tanam selanjutnya. $\mathrm{Na}$ mun demikian, terdapat kecenderungan bahwa varietas-varietas padi berumur pendek biasanya memberikan hasil yang lebih rendah dikarenakan kurang cukupnya pertumbuhan vegetatif untuk mendukung tingkat hasil yang maksimal 
(Yoshida, 1976). Varietas padi berumur genjah dapat dikelompokkan menjadi tiga, yaitu: ultra genjah (umur kurang dari 90 hari setelah tanam), sangat genjah (umur 90-104 hari setelah tanam), dan genjah (umur 105-125 hari setelah tanam) (Balai Penelitian Tanaman Padi, 2014). Varietas padi berumur genjah dan produktivitas tinggi dimungkinkan dapat diperoleh melalui berbagai pendekatan baik secara fenotipik, morfologis maupun fisiologis (Dingkuhn et al., 1991; Peng et al., 1994). Ketersediaan koleksi sumber daya genetik (SDG) padi pada tingkat keragaman (diversitas) yang memadai akan sangat mendukung keberhasilan program pemuliaan untuk mendapatkan varietas unggul tersebut (Guimaraes, 2009).

Karakter morfo-fisiologis tanaman, seperti ketebalan daun dan laju pertumbuhan tanaman merupakan karakteristik tanaman yang mempengaruhi tingkat produktivitas tanaman, karena dapat mempengaruhi kecepatan proses fotosintesis tanaman. Laju pengisian biji yang besar dan relatif lama akan menghasilkan bobot biji yang tinggi selama biji sebagai sink dapat menampung hasil asimilat. Sebaliknya bila sink cukup banyak tetapi hasil asimilat rendah dapat mengakibatkan kehampaan pada biji. Keterbatasan source sering terjadi pada periode pengisian biji, tetapi keterbatasan sink terjadi jika dalam kondisi tanpa cekaman (Egli, 1999).

Laju pertumbuhan tanaman antar genotipe berbeda-beda. Pengamatan karakter fisiologis plasma nutfah padi, seperti laju pertumbuhan yang dimanifestasikan oleh laju asimilasi bersih, laju pertumbuhan relatif, laju pengisian biji, laju daun menua (senescense) dan berat spesifik daun belum banyak dievaluasi. Karakter lamanya proses pertumbuhan vegetatif dan generatif yang dicerminkan oleh umur panen dan besaran laju pertumbuhan bagian tanaman serta kapa- sitas source dan sink tanaman akan menentukan tingkat produktivitas tanaman. Laju asimilasi bersih (Net Assimilation Rate - NAR) menentukan laju pertumbuhan relatif (relative growth rate $R G R)$ (Shipley, 2006), sedangkan korelasi SLA (Specific Leaf Area) dengan LWR (Leaf Weight Ratio) lemah dan berubah-ubah (Shipley, 2002). Hasil simulasi pada tanaman padi menunjukkan bila SLA menurun maka hasil biji akan menurun (Aggarwal, 1995). Di samping itu, Crop Growth Rate (CGR) selama fase reproduktif akhir (140 hari sebelum heading penuh) berkorelasi erat dengan hasil bji. Genotipe yang memiliki CGR tinggi selama perode tersebut menghasilkan jumlah gabah yang tinggi per satuan luas. Fotosintesis dari kanopi tanaman selama periode akhir fase reproduktif akhir merupakan hal yang esensial untuk peningkatan potensi produksi padi. Hasil biji per satuan luas sangat ditentukan oleh besarnya komponen hasil tanaman, seperti jumlah biji bernas dan hampa tiap malai, ukuran butir, jumlah anakan dan jumlah malai. Tujuan dari penelitian ini adalah melakukan kajian/ evaluasi karakter-karakter morfo-fisiologis pada SDG padi berumur genjah, untuk mengidentifikasi aksesi-aksesi yang berpotensi untuk dikembangkan sebagai varietas unggul padi dengan produktivitas tinggi dan umur genjah.

\section{BAHAN DAN METODE}

Penelitian dilakukan di Kebun Percobaan Balai Besar Penelitian dan Pengembangan Padi (Balitpa) Sukamandi, menggunakan sebanyak 25 aksesi plasma nutfah padi berumur genjah. Rancangan percobaan yang digunakan adalah Rancangan Acak Kelompok dengan 3 ulangan. Pupuk yang diberikan sebanyak 300 kg Urea, $100 \mathrm{~kg}$ SP36 dan $50 \mathrm{~kg} \mathrm{KCl}$ per hektar. Pengendalian hama dan penyakit serta gulma dilakukan secara optimal. 
Laju pertumbuhan yang diamati meliputi laju asimilasi bersih (Net Assimilation Rate - NAR), laju pertumbuhan relatif (Relative Growth Rate - RGR), laju pengisian biji, dan laju daun menua (senescense). Laju asimilasi bersih dihitung menggunakan persamaan: $N A R=\left(\left(\mathrm{W}_{2}-\mathrm{W}_{1}\right) /\left(\mathrm{t}_{2}-\mathrm{t}_{1}\right)\right)\left(\left(\ln \mathrm{A}_{2}\right.\right.$ - $\left.\left.\ln A_{1}\right) /\left(A_{2}-A_{1}\right)\right)$ dan laju petumbuhan relatif sebagai $R G R=\left(\ln \mathrm{W}_{2}-\ln \mathrm{W}_{1}\right) /\left(\mathrm{t}_{2}-\mathrm{t}_{1}\right), \mathrm{W}_{1}$ dan $\mathrm{W}_{2}$ merupakan bobot tanaman pada waktu $t_{1}$ dan $t_{2}$, $A_{1}$ dan $A_{2}$ sebagai luas daun pada waktu $t_{1}$ dan $t_{2}$ (William dan Joseph, 1976). Laju pengisian biji diduga dari bobot biji saat panen dibagi selisih antara waktu panen dan mulai pengisian biji (mulai keluar malai). Karakteristik daun yang diamati meliputi: luas spesifik daun (Specific Leaf Area - SLA), rasio bobot daun (Leaf Mass Ratio - LMR), rasio luas daun (Leaf Area Ratio - LAR) dan indeks luas daun (Leaf Area Index - LAI) (Morrison et al., 1999). Luas spesifik daun (SLA) merupakan luas daun dibagi bobot kering daun. Rasio luas daun (LAR) ditentukan sebagai luas daun dibagi bobot kering tanaman, sedangkan rasio bobot daun (LMR) adalah bobot daun kering dibagi bobot kering tanaman. Indek luas daun (LAI) merupakan luas daun maksimum dibagi luas lahan di mana tanaman tumbuh.

Identifikasi laju pertumbuhan tanaman padi dilakukan dengan menggunakan teknik destruktif, yaitu memotong 5 tanaman/rumpun kompetitif tiap minggu dimulai dari tanaman berumur 30 hari hingga panen. Bagian-bagian tanaman batang, daun, dan malai/gabah dipisahkan dari tanaman kemudian dikeringkan dalam oven pada suhu sekitar $60-70^{\circ} \mathrm{C}$ selama 36 jam. Luas daun hijau tanaman padi tiap helai diduga dengan mengukur panjang (P) dan lebar maksimum (L) daun. Luas daun tiap helai dihitung menggunakan persamaan: 0,76 x P x L (Gomez, 1976).
Analisis varians (analysis of variance - Anova) dilakukan terhadap data laju asimilasi bersih (Net Assimilation Rate - NAR), laju pertumbuhan relatif (Relative Growth Rate - RGR), laju pengisian biji, dan laju daun menua (senescence); serta data karakteristik daun, yaitu: luas spesifik daun (Specific Leaf Area - SLA), rasio bobot daun (Leaf Mass Ratio - LMR), rasio luas daun (Leaf Area Ratio - LAR) dan indeks luas daun (Leaf Area Index - LAI). Analisis korelasi dilakukan pada data luas spesifik daun (SLA), rasio luas daun (LAR), rasio bobot daun (LMR) dan indeks luas daun (LAI), terhadap hasil gabah. Analisis data dikerjakan menggunakan perangkat lunak Minitab versi 16 (Minitab Inc.).

\section{HASIL DAN PEMBAHASAN}

Karakter pertumbuhan plasma nutfah padi berumur genjah

Analisis komponen pertumbuhan dan hasil dapat digunakan untuk mengkuantifikasi kontribusi bobot awal tanaman, laju pertumbuhan relatif terhadap keragaman genetik sebagai dasar pemilihan kriteria seleksi pada pemuliaan tanaman (Sparnaaij et al., 1996). Pola sebaran pertumbuhan bagian tanaman (daun, batang dan malai) selama pertumbuhan hampir serupa dari 25 varietas/galur yang dievaluasi. Pada saat panen, porsi malai sekitar 50\% dari total bahan kering tanaman bagi varietas Dodokan dan galur B11742-RS-2-3-MR-34-1-2-3, sedangkan bagi varietas Nona Bokra porsi malai sekitar 30\% dari total bahan kering (Gambar 1-3). 


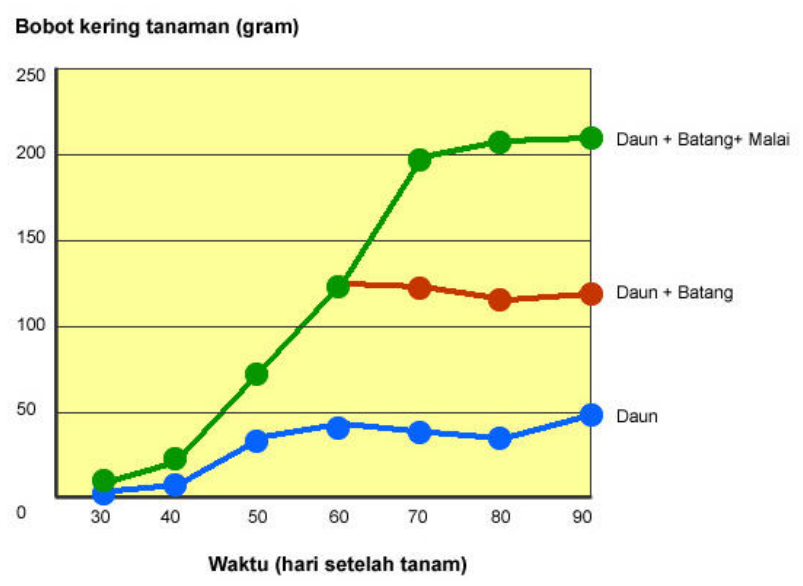

Gambar 1. Distribusi bagian tanaman (daun, batang dan malai) varietas Dodokan

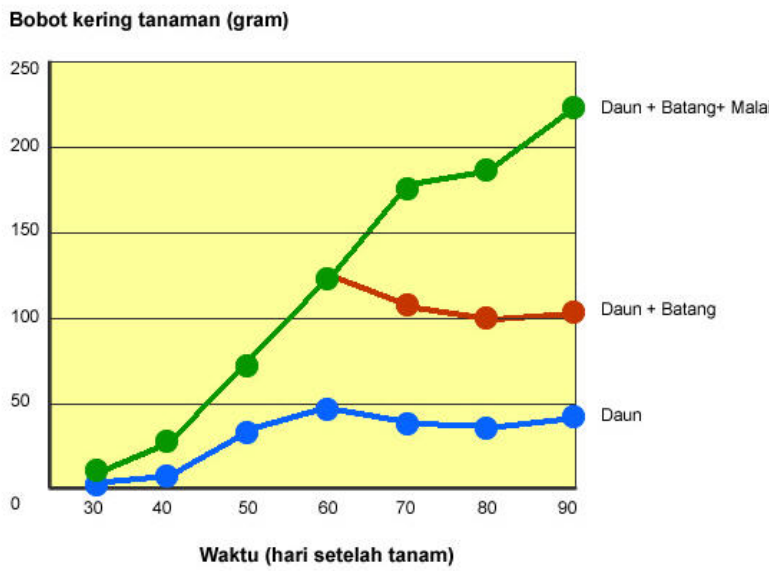

Gambar 2. Distribusi bagian tanaman (daun, batang dan malai) galur B11742-RS-2-3-MR-34-1-2-3

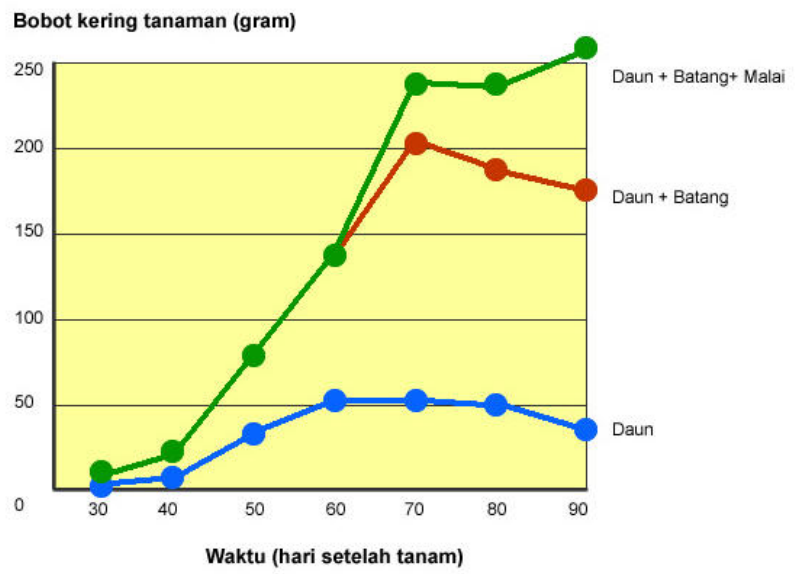

Gambar 3. Distribusi bagian tanaman (daun, batang dan malai) varietas Nona Bokra
Hasil analisis korelasi antara NAR, RGR dengan bobot gabah padi memberikan hasil tidak nyata. Hal tersebut mengindikasikan bahwa NAR dan RGR selama proses pertumbuhan (vegetatif) dan perkembangan (generatif) tidak seluruhnya berkontribusi nyata terhadap hasil gabah / biji. Periode perkembangan (generatif) yang relatif lebih pendek, merupakan fase yang secara langsung berkaitan dengan proses pembentukan, pengisian dan pemasakan biji. NAR dan RGR selama pertumbuhan tanaman padi umumnya memperlihatkan fenomena meningkat (tinggi) pada awal fase pertumbuhan, untuk selanjutnya menurun secara cepat seiring dengan umur tanaman (Sridevi \& Chellamuthu, 2015). NAR yang berlangsung antara 40-50 hari setelah tanam (hst) berkorelasi positif lemah dengan hasil gabah (Tabel 1). Periode pertumbuhan pada 40-50 hari setelah tanam merupakan fase perkembangan (generatif), di mana proses pembentukan dan pengisian biji (fase bunting) dimulai. Hasil tersebut memberi petunjuk bahwa perkembangan tanaman menjelang fase bunting merupakan masa yang berkontribusi dalam menentukan produktivitas tanaman padi.

Tabel 1. Korelasi antar hasil gabah padi dengan NAR dan $R G R$

\begin{tabular}{lc}
\hline Laju pertumbuhan NAR - RGR & Hasil gabah padi \\
\hline NAR: $30-40$ hst & $-0,2039$ \\
$R G R: 30-40$ hst & 0,0048 \\
NAR: $40-50$ hst & 0,1810 \\
$R G R: 40-50$ hst & 0,0673 \\
NAR: $50-60$ hst & $-0,0849$ \\
$R G R: 50-60$ hst & $-0,1692$ \\
NAR: $60-70$ hst & $-0,0195$ \\
$R G R: 60-70$ hst & $-0,0613$ \\
\hline
\end{tabular}

Pertanaman yang memiliki RGR tinggi pada fase awal diharapkan mampu bersaing dengan gulma dalam memanfaatkan hara tanaman. Hasil pengamatan RGR yang relatif tinggi pada 
umur 30-40 hst yaitu varietas Danau Tempe dan galur B11742-RS-2-3-MR-34-1-1-5 dan pada umur 40-50 hst yaitu IR2061-6-9, Danau Atas dan B.10970C-MR-4-2-1-1-1-S1-3-2-4-1. Sementara itu NAR pada fase awal (30-40 hst) yang relatif tinggi dimiliki oleh Danau Tempe (Tabel 2). Nilai NAR terlihat berkorelasi positip dengan RGR sebagaimana hasil penelitian yang dilakukan oleh Veneklaas \& Poorter (1998), sehingga NAR ini dapat digunakan sebagai determinan utama nilai RGR.

Tabel 2. NAR dan RGR pada umur 30-40 hari setelah tanam (hst) dan 40-50 hst

\begin{tabular}{llcccc}
\hline \multirow{2}{*}{ No. } & Varietas & \multicolumn{2}{c}{ Umur $30-40$ hst } & \multicolumn{2}{c}{ Umur $40-50 \mathrm{hst}$} \\
\cline { 3 - 5 } & & NAR & RGR & NAR & RGR \\
\hline 1. & Panada & 0,0011 & 0,1092 & 0,0009 & 0,0858 \\
2. & IR2061-6-9 & 0,0010 & 0,1061 & 0,0016 & 0,1501 \\
3. & Maninjau & 0,0013 & 0,1102 & 0,0013 & 0,1153 \\
4. & Mahakam & 0,0012 & 0,1353 & 0,0011 & 0,1192 \\
5. & Danau Atas & 0,0006 & 0,0845 & 0,0014 & 0,1492 \\
6. & Limut & 0,0006 & 0,1001 & 0,0007 & 0,1002 \\
7. & Lariang & 0,0011 & 0,0989 & 0,0012 & 0,1143 \\
8. & Danau Tempe & 0,0041 & 0,1678 & 0,0001 & 0,0360 \\
9. & Jatiluhur & 0,0009 & 0,1140 & 0,0010 & 0,1080 \\
10. & Nona Bokra & 0,0011 & 0,1044 & 0,0015 & 0,1327 \\
11. & B.10970C-MR-4-2-1-1-1-SI-3-2-4-1 & 0,0008 & 0,0784 & 0,0016 & 0,1460 \\
12. & B.11283-6C-PN-5-MR-2-3-SI-1-2-1-1 & 0,0008 & 0,0791 & 0,0012 & 0,1201 \\
13. & B11283-6C-PN-5-MR-34-1-1-3 & 0,0010 & 0,1203 & 0,0011 & 0,1101 \\
14. & B11742-RS-2-3-MR-34-1-1-3 & 0,0008 & 0,1051 & 0,0012 & 0,1269 \\
15. & B11742-RS-2-3-MR-34-1-1-4 & 0,0011 & 0,1222 & 0,0012 & 0,1260 \\
16. & B11742-RS-2-3-MR-34-1-1-5 & 0,0013 & 0,1597 & 0,0008 & 0,0859 \\
17. & B11742-RS-2-3-MR-34-1-2-1 & 0,0007 & 0,0922 & 0,0012 & 0,1266 \\
18. & B11742-RS-2-3-MR-34-1-2-3 & 0,0010 & 0,1035 & 0,0010 & 0,0953 \\
19. & B11742-RS-2-3-MR-34-1-4-1 & 0,0007 & 0,0840 & 0,0012 & 0,1277 \\
20. & B11742-RS-2-3-MR-34-1-4-3 & 0,0011 & 0,1083 & 0,0014 & 0,1322 \\
21. & Dodokan & 0,0013 & 0,1185 & 0,0009 & 0,0765 \\
22. & Silugonggo & Sondano & 0,1262 & 0,0008 & 0,0877 \\
\hline
\end{tabular}

Laju pengisian biji B11283-6C-PN-5-

MR-34-1-1-3, Lariang, B11742-RS-2-3-MR-34-1-2-3 memiliki 1.0-1.3 g/rumpun/hari selama waktu periode pengisian biji sedangkan varietas Dodokan dan Silugonggo memiliki laju pengisian biji 0.7-0.8 g/rumpun/hari (Tabel 3). Varietas Panada dan Limut yang dievaluasi ternyata berumur panjang. Pada saat varietas yang lain telah dipanen pada umur 95-99 hari, kedua varietas tersebut baru keluar malai. Hasil gabah relatif tinggi dibanding varietas Dodokan dan Silugonggo yaitu Danau Atas, B.11283-6C-PN-5MR-2-3-Sl-1-2-1-1, B11742-RS-2-3-MR-34-1-2-3 dan B11742-RS-2-3-MR-34-1-4-1.

Tabel 3. Laju pengisian biji, umur keluar malai dan umur panen varietas /galur padi

\begin{tabular}{|c|c|c|c|c|c|}
\hline No. & Varietas & $\begin{array}{l}\text { Umur } \\
\text { keluar } \\
\text { malai } \\
\text { (hari) }\end{array}$ & $\begin{array}{c}\text { Umur } \\
\text { panen } \\
\text { (hari) }\end{array}$ & $\begin{array}{c}\text { Hasil } \\
\text { gabah } \\
(\mathrm{kg} / \\
\mathrm{ha})\end{array}$ & $\begin{array}{c}\text { Laju } \\
\text { pengisian } \\
\text { biji (g/ } \\
\text { hari/ } \\
\text { rumpun) }\end{array}$ \\
\hline 1. & Panada & * & * & * & * \\
\hline 2. & IR2061-6-9 & 74,0 & 98,0 & 5844 & 1,2 \\
\hline 3. & Maninjau & 72,7 & 98,3 & 4558 & 0,9 \\
\hline 4. & Mahakam & 72,3 & 98,0 & 4330 & 0,8 \\
\hline 5. & Danau Atas & 71,7 & 98,0 & 6184 & 1,2 \\
\hline 6. & Limut & * & * & * & \\
\hline 7. & Lariang & 75,3 & 98,0 & 5693 & 1,3 \\
\hline 8. & Danau Tempe & 63,7 & 95,0 & 5926 & 0,9 \\
\hline 9. & Jatiluhur & 60,3 & 95,7 & 4949 & 0,7 \\
\hline 10. & Nona Bokra & 69,7 & 96,7 & 4647 & 0,9 \\
\hline 11. & B.10970C-MR-4-2-1-1-1-SI-3-2-4-1 & 67,0 & 97,3 & 5902 & 1,0 \\
\hline 12. & B.11283-6C-PN-5-MR-2-3-SI-1-2-1-1 & 62,0 & 96,0 & 6036 & 0,9 \\
\hline 13. & B11283-6C-PN-5-MR-34-1-1-3 & 70,7 & 97,0 & 5636 & 1,1 \\
\hline 14. & B11742-RS-2-3-MR-34-1-1-3 & 59,7 & 96,7 & 5696 & 0,8 \\
\hline 15. & B11742-RS-2-3-MR-34-1-1-4 & 65,7 & 96,0 & 5607 & 0,9 \\
\hline 16. & B11742-RS-2-3-MR-34-1-1-5 & 61,3 & 96,0 & 5694 & 0,8 \\
\hline 17. & B11742-RS-2-3-MR-34-1-2-1 & 65,7 & 97,3 & 5810 & 0,9 \\
\hline 18. & B11742-RS-2-3-MR-34-1-2-3 & 61,0 & 94,3 & 6466 & 1,0 \\
\hline 19. & B11742-RS-2-3-MR-34-1-4-1 & 59,3 & 95,3 & 6007 & 0,8 \\
\hline 20. & B11742-RS-2-3-MR-34-1-4-3 & 60,3 & 96,3 & 4904 & 0,7 \\
\hline 21. & Dodokan & 64,7 & 96,0 & 4948 & 0,8 \\
\hline 22. & Silugonggo & 58,7 & 95,3 & 4971 & 0,7 \\
\hline 23. & Sentani & 69,7 & 96,7 & 3301 & 0,6 \\
\hline 24. & Tondano & 70,0 & 97,3 & 5460 & 1,0 \\
\hline 25. & Singkarak & 62,7 & 97,3 & 5831 & 0,8 \\
\hline
\end{tabular}


Karakter morfologi daun plasma nutfah padi berumur genjah

Hasil pengamatan menunjukkan bahwa LMR pada umur 30 hari dari varietas yang diuji yang memiliki dua nilai terbesar adalah Nona Bokra dan B11283-6C-PN-5-MR-2-3-SI-1-2-1-1. Kedua varietas ini ini diharapkan memiliki komponen karakter starter awal pertumbuhan. Namun setelah berumur 70 hari kemudian kedua varietas tersebut tidak memiliki LMR terbesar. Nampaknya hasil fotosintat pada fase awal ini dialokasikan untuk perkembangan batang tanaman. LMR sebagai indikator kapasitas source untuk menghasilkan fotosintat. Hasil penelitian menunjukkan adanya korelasi lemah antara LMR dengan bobot biji. Hal tersebut mengindikasikan bahwa kapasitas source belum tentu secara langsung menentukan kuantitas hasil fotosintat. Perlu diperhitungkan pula faktor lain yang dapat mempengaruhi proses fotosintesis, seperti intensitas cahaya pada lingkungan tempat pertumbuhan (Poorter \& Van der Werf, 1998; Shipley, 2002).

Tabel 4. Korelasi antara hasil gabah dengan SLA, LAR, LMR dan LAI

\begin{tabular}{cccc}
\hline Karakter & Hasil gabah & Karakter & Hasil gabah \\
\hline SLA-30 hst & 0,3204 & SLA-60 hst & $-0,2001$ \\
LAR-30 hst & 0,2436 & LAR-60 hst & $-0,0842$ \\
LMR-30 hst & 0,3977 & LMR-60 hst & $-0,1514$ \\
LAl-30 hst & $0,4443^{*}$ & LAl-60 hst & 0,2304 \\
SLA-40 hst & 0,2936 & SLA-70 hst & $-0,2034$ \\
LAR-40 hst & 0,1546 & LAR-70 hst & $-0,1094$ \\
LMR-40 hst & 0,0970 & LMR-70 hst & $-0,1161$ \\
LAl-40 hst & 0,2233 & LAl-70 hst & 0,1030 \\
SLA-50 hst & 0,1261 & SLA-80 hst & $-0,1971$ \\
LAR-50 hst & 0,0431 & LAR-80 hst & $-0,1852$ \\
LMR-50 hst & $-0,0998$ & LMR-80 hst & $-0,1926$ \\
LAl-50 hst & 0,1885 & LAl-80 hst & 0,0972 \\
\hline
\end{tabular}

Luas spesifik daun (SLA) sebagai perbandingan luas daun dengan berat daun yang menunjukkan apabila semakin besar nilai SLA mengin- dikasikan daun semakin tipis. Hasil simulasi pada tanaman padi bila SLA menurun maka hasil biji akan menurun (Aggarwal, 1995). Hasil penelitian ini mengindikasikan adanya korelasi positif antara SLA fase awal dengan bobot gabah (Tabel 4). SLA sebagai indikasi ketebalan daun, daun yang relatif lebih tipis dibandingkan varietas/galur yang lain yaitu varietas Maninjau, Jatiluhur, galur B.11283-6C-PN-5-MR-2-3-SL-1-2-1-1, Dodokan dan Silugonggo (Tabel 5). LAR, LMR dan LAI yang tinggi pada saat tanaman berumur 70 hari ditunjukkan oleh varietas Panada dan Limut. Hal ini menujukkan bahwa kedua varietas tersebut lebih banyak menghasilkan daun. Sementara itu SLA, LAR, LMR dan LAI dari galur-galur yang ada nampak tidak berbeda dengan varietas Dodokan dan Silugonggo.

Karakteristik daun SLA dan LMR menentukan laju pertumbuhan relatif tanaman (Shipley, 2006). Korelasi antara SLA, LAR, LMR dan LAI dengan hasil gabah menunjukkan bahwa karakter tersebut pada tanaman berumur 30 hari relatif lebih tinggi dibandingkan dengan fase selanjutnya. LAI umur 30 hst nyata berkorelasi positif dengan hasil gabah (Tabel 4). Hal ini menunjukkan bahwa perkembangan luas daun pada saat awal dapat menentukan produktivitas tanaman padi. LAR merupakan rasio luas daun dengan berat tanaman pada fase tanaman setelah berumur 60 hst yang memiliki korelasi negatif dengan bobot biji. Dengan demikian dapat dikatakan bahwa makin luas daun tanaman padi maka akan menghasilkan bobot biji rendah.

Tingkat produktivitas merupakan salah satu keragaan tanaman yang sangat dipengaruhi oleh rangkaian proses fisiologis, yang merupakan fungsi dari berbagai komponen pertumbuhan dan perkembangan tanaman, serta macam kultivar yang juga dapat berperan sebagai faktor pembatas. Oleh karena itu, identifikasi aspek fisiolo- 
gis melalui analisis keragaan berbagai komponen yang mempengaruhi hasil (yield) sangat penting untuk dilakukan (Gardner et al., 1985).

Tabel 5. Karakteristik morfo-fisiologis tanaman padi pada umur 70 hari

\begin{tabular}{rlllll}
\hline No. & \multicolumn{1}{c}{ Varietas/galur } & SLA & LAR & LMR & LAI \\
\hline 1. & Panada & 177 & 76 & 0,38 & 7,74 \\
2. & IR2061-6-9 & 168 & 49 & 0,28 & 4,77 \\
3. & Maninjau & 194 & 53 & 0,28 & 3,59 \\
4. & Mahakam & 218 & 75 & 0,34 & 5,67 \\
5. & Danau Atas & 196 & 57 & 0,28 & 6,20 \\
6. & Limut & 199 & 74 & 0,38 & 8,59 \\
7. & Lariang & 198 & 55 & 0,27 & 6,20 \\
8. & Danau Tempe & 181 & 57 & 0,30 & 4,56 \\
9. & Jatiluhur & 203 & 49 & 0,26 & 4,31 \\
10. & Nona Bokra & 179 & 39 & 0,22 & 4,70 \\
11. & B.10970C-MR-4-2-1-1-1-SI-3-2-4-1 & 178 & 57 & 0,27 & 4,75 \\
12. & B.11283-6C-PN-5-MR-2-3-SI-1-2-1-1 & 218 & 59 & 0,30 & 4,01 \\
13. & B11283-6C-PN-5-MR-34-1-1-3 & 199 & 57 & 0,28 & 5,16 \\
14. & B11742-RS-2-3-MR-34-1-1-3 & 195 & 43 & 0,22 & 3,85 \\
15. & B11742-RS-2-3-MR-34-1-1-4 & 188 & 50 & 0,25 & 4,53 \\
16. & B11742-RS-2-3-MR-34-1-1-5 & 190 & 47 & 0,23 & 3,74 \\
17. & B11742-RS-2-3-MR-34-1-2-1 & 187 & 43 & 0,22 & 4,21 \\
18. & B11742-RS-2-3-MR-34-1-2-3 & 186 & 43 & 0,23 & 3,78 \\
19. & B11742-RS-2-3-MR-34-1-4-1 & 194 & 30 & 0,16 & 2,99 \\
20. & B11742-RS-2-3-MR-34-1-4-3 & 199 & 42 & 0,21 & 3,26 \\
21. & Dodokan & 208 & 43 & 0,22 & 4,07 \\
22. & Silugonggo & 215 & 43 & 0,20 & 2,72 \\
23. & Sentani & 183 & 52 & 0,28 & 4,00 \\
24. & Tondano & 217 & 52 & 0,27 & 5,28 \\
25. & Singkarak & 55 & 0,29 & 3,64 \\
\hline
\end{tabular}

Analisis keragaan komponen-komponen pertumbuhan dan perkembangan tanaman tersebut tidak hanya dapat digunakan untuk mengevaluasi tingkat produktivitas, namun juga efisiensi fisiologis tanaman dalam memanfaatkan sumber daya lingkungan, misalnya efisiensi pemanfaatan unsur hara (pupuk) (Anzoua et al., 2010; De Sclaux et al., 2000). Kultivar-kultivar padi yang menunjukkan keragaan fisiologis yang lebih tinggi mengindikasikan bahwa kultivarkultivar tersebut memiliki keragaan pertumbuhan dan perkembangan lebih baik, yang pada gilirannya memberikan hasil yang lebih tinggi (Esfahani et al., 2006; Katsura, 2007; Mahdavi et al., 2006). Galur-galur berumur sangat genjah (96 hari setelah tanam) seperti Danau Atas, B.11283-6C-PN-5-MR-2-3-Sl-1-2-1-1, B11742-RS2-3-MR-34-1-2-3 dan B11742-RS-2-3-MR-34-1-4-1 memperlihatkan penampilan yang sangat baik. Bahkan galur-galur B11742-RS-2-3-MR-34-1-1-3, B11742-RS-2-3-MR-34-1-1-4 dan B11742-RS-2-3MR-34-1-4-1 menghasilkan produksi gabah lebih tinggi dibandingkan dengan varietas Silugonggo dan Dodokan. Galur-galur tersebut memiliki potensi besar untuk dikembangkan lebih lanjut sebagai kandidat varietas unggul.

\section{SIMPULAN}

Pola sebaran pertumbuhan bagian tanaman (daun, batang dan malai) selama pertumbuhan hampir serupa dari 25 varietas atau galur yang dievaluasi. Diketahui bahwa NAR, RGR dan LMR berkorelasi tidak nyata terhadap bobot gabah padi. Galur-galur berumur sangat genjah (96 hari setelah tanam) seperti Danau Atas, B.11283-6C-PN-5-MR-2-3-Sl-1-2-1-1, B11742-RS2-3-MR-34-1-2-3 dan B11742-RS-2-3-MR-34-1-4-1 memperlihatkan penampilan yang sangat baik. Bahkan galur-galur B11742-RS-2-3-MR-34-1-1-3, B11742-RS-2-3-MR-34-1-1-4 dan B11742-RS-2-3MR-34-1-4-1 menghasilkan produksi gabah lebih tinggi dibandingkan dengan varietas Silugonggo dan Dodokan. Galur-galur tersebut memiliki potensi besar untuk dikembangkan lebih lanjut sebagai kandidat varietas unggul.

\section{UCAPAN TERIMA KASIH}

Penulis menyampaikan terima kasih kepada Dr. Buang Abdullah, peneliti dari BB Padi - Sukamandi yang telah memberikan benih varietas dan galur-galur padi untuk penelitian ini. 


\section{DAFTAR PUSTAKA}

Aggarwal, P.K. 1995. Plant type designs for increased yield potential of irrigated rice- simulation analysis. In Aggarwal, P.K., R.B. Mattews, M.J. Kroff \& H. H. van Laar (Eds). SARP Research Proceedings. IRRI. Los Banos. pp.59-66.

Akita S. 1989. Improving yield potential in tropical rice. In: Progress in irrigated rice research. Proceedings of International Rice Research Conference, pp. 21-25, Hangzhou, China.

Anzoua KG, Junichi K, Toshihiro H, Kazuto I, and Yutaka J. 2010. Genetic improvements for high yield and low soil nitrogen tolerance in rice (Oryza sativa L.) under a cold environment. Field Crops Research 116, 38-45.

Balai Penelitian Tanaman Padi. 2014. Hasil penelitian padi T.A 2013 Buku 1: Plasma Nutfah, Pemuliaan dan Perbenihan. Badan Penelitian dan Pengembangan Pertanian Kementerian Pertanian.

De Sclaux D, Huynh TT, and Roumet P. 2000. Identification of soybean plant characteristics that indicate the timing of drought stree. Crop Science 40, 716-722.

Dingkuhn, M., Penning de Vries, F.W.T., De Datta, S.K., and van Laar, H.H., 1991. Concepts for a new plant type for direct seeded flooded tropical rice In: DirectSeeded Flooded Rice in the Tropics. International Rice Research Institute. P.O. Box 933, M Philippines, 17-38.

Egli D.B. 1999. Variation in leaf starch and sink limitations during seed filling in soybean. Crop Sci., 39: 1361-1368.

Esfahani M, Sadrzadelr S, Kavoossi M, and Dabagh Mohammadi Nasab A. 2006. Study the effect of different levels of nitrogen and potassium fertilizers on growth, grain yield, yield components of rice cultivar khazar. Iranian Journal of Crop Sciences 3, 226-242.

Gardner F, Pearce R, and Mitchell RL. 1985. Physiology of crop plants. lowa State University Press. Ames. USA.

Gomez, 1976. Statistical procedures for agricultural research with emphasis on rice. Los Banos, Philippines: International Rice Research Institute, 1976. 294 p.

Guimares, E. P. 2009. Rice Breeding. In: Cereals, The Banks and the Italian Economy. M.J. Carena (ed.) XIV, Springer Science + Business Media, LLC. 426p. (pp. 99-126).

Katsura K, Maeda S, Horie T, and Shiraiwa T. 2007. Analysis of yield attributes and crop physiological traits of Liangyoupeijiu, a hybrid rice recently bred in China. Field Crops Research 103, 170-177.

Mahdavi F, Esmaeili MA, Fallah A, and Pirdashti H. 2006. Study of morphological characteristcs, physiological indices, grain yield and its components in rice (Oryza sativa L.) landraces and improved cultivar. Iranian Journal of Crop Sciences. 7(4), 280-297.

Morrison, M.J., H.D. Voldeng and E.R. Cober. 1999. Physiological changes from 58 years of genetic improvement of shortseason soybean cultivars in Canada. Agron. J. 91: 685-689.

Peng, S., Khush, G.S., and Cassman, K.G., 1994. Evolution of the new plant ideotype for increased yield potential. In: Cassman, K.G. (Ed.), Proceedings of a Workshop on Rice Yield Potential in Favorable Environments. International Rice Research Institute, Philippines, pp. 5-20.
Poorter, H. and Van Der Werf, A. 1998. Is inherent variation in RGR determined by LAR at low irradiance and by NAR at high irradiance? A Review of Herbaceous Species. Inherent Variation in Plant Growth. Physiological Mechanisms and Ecological Consequences (eds H. Lambers, H. Poorter and M.M.I. Van Vuuren), pp. 309-336. Backhuys, Leiden, the Netherlands.

Shipley, B. 2002. Trade-Offs between Net Assimilation Rate and Specific Leaf Area in Determining Relative Growth Rate: Relationship with Daily Irradiance. Funct. Ecol. 16: 682-689

Shipley, B. 2006. Net assimilation rate, specific leaf area and leaf mass ratio: which is most closely correlated with relative growth rate? A meta-analysis. Funct. Ecol. 20:565-574.

Sparnaaij L. D., H. J. J. Koehorst-van Putten, and I. Bos. 1996. Component analysis of plant dry matter production: a basis for selection of breeding parents as illustrated in carnation. Euphytica 90 (2): 183-194.

Sridevi, V. and Chellamuthu, V. 2015. Growth analysis and yield of rice as affected by different System of Rice Intensification (SRI) practices. International Journal of Research in Applied, Natural and Social Sciences. Vol. 3(4): 29-36.

Tanaka T. 1976. Regulation of plant type and carbon assimilation of rice. JARQ, 10(4):161-167.

Veneklaas, E.J. and Poorter, L. 1998. Growth and carbon partitioning of tropical tree seedlings in contrasting light environments. Inherent Variation in Plant Growth. Physiological Mechanisms and Ecological Consequences (eds H. Lambers, H. Poorter and M.M.I. Van Vuuren), pp. 337-361. Backhuys, Leiden, the Netherlands.

Williams C.N., and K. T. Joseph. 1976. Climate, soil and crop production in the humid tropics. Oxford Univ. Press. Kuala Lumpur.

Yoshida S (1976). Physiological consequences of altering plant type and maturity. In: Proceedings of The International. Rice Research Institute (IRRI). Los Banos, Phillippines. 